\title{
The concept of 'logic' and 'logical' in the official documents of the Pope Benedict XVI in comparison with the approach present in John Paul II encyclicals
}

\author{
Włodzimierz Lapis \\ FACULTY OF LINGUISTICS, ADAM MICKIEWICZ UNIVERSITY IN POZNAŃ \\ AL. NIEPODLEGŁOŚCI 4, 60-874, POZNAŃ - POLAND \\ lapisw@amu.edu.pl

\begin{abstract}
The article discusses the meaning of the words 'logic' and 'logical' as used by Pope Benedict XVI in the Encyclicals and Apostolic Exhortations. The approach of Benedict XVI is then compared with that of Pope John Paul II (as analyzed in Lapis (2011)).
\end{abstract}

\section{Introduction}

The official papal documents include Encyclicals and Apostolic Exhortations. Pope Benedict XVI (Joseph Ratzinger) during his pontificate (April 19, 2005 - February 28, 2013) wrote and published three encyclicals and four apostolic exhortations, in which (in the English language version) the word 'logic' and 'logical' occur the following number of times (documents are presented here in the chronological order): 
Tab. 1

\begin{tabular}{|c|c|c|c|c|}
\hline LP & Type of document & Document name & $\begin{array}{l}\text { Date of } \\
\text { publication }\end{array}$ & $\begin{array}{l}\text { The } \\
\text { number } \\
\text { of words } \\
\text { 'logic' and } \\
\text { 'logical' }\end{array}$ \\
\hline 1 & Encyclical & Deus caritas est (God is love) & 25 I 2006 & o \\
\hline 2 & Apostolic exhortation & $\begin{array}{l}\text { Sacramentum Caritatis (The } \\
\text { Sacrament of Charity) }\end{array}$ & 22 II 2007 & o \\
\hline 3 & Encyclical & Spe salvi (Saved in hope) & $30 \mathrm{XI} 2007$ & 1 \\
\hline 4 & Encyclical & Caritas in veritate (Love in Truth) & 29 VI 2009 & 14 \\
\hline 5 & Apostolic exhortation & $\begin{array}{l}\text { Verbum Domini (The Word of the } \\
\text { Lord) }\end{array}$ & 30 IX 2010 & 2 \\
\hline 6 & Apostolic exhortation & $\begin{array}{l}\text { Africae Munus (The Pledge for } \\
\text { Africa) }\end{array}$ & $19 \mathrm{XI} 2011$ & 2 \\
\hline 7 & Apostolic exhortation & $\begin{array}{l}\text { Ecclesia in Medio Oriente (The } \\
\text { Church in the Middle East) }\end{array}$ & 14 IX 2012 & O \\
\hline
\end{tabular}

As shown in Table 1, in the researched documents these words are distributed rather unevenly: 15 in 2 out of 3 encyclicals and 4 in 2 out of 4 apostolic exhortations. While describing the results below, we will quote passages of texts containing these fragments.

\section{The concept of logic in terms of time}

This type of approach might be observed in two out of four documents.

The first is the Encyclical SPE SALVI, which contains only one-passage, with a word referring to logic ('logically'):

21. Marx not only omitted to work out how this new world would be organized-which should, of course, have been unnecessary. His silence on this matter follows logically from his chosen approach. His error lay deeper. He forgot that man always remains man. He forgot man and he forgot man's freedom. He forgot that freedom always remains also freedom for evil.

We read from it, that if someone does not think about something, it's no wonder that later he does not talk about it (because it is simply the 'logical consequence'). It is the only excerpt of the set of documents considered here, where we deal with this type of term, describing directly the logical consequence.

Similarly, one fragment (but this time with two instances of the word 'logic') occurs in the Apostolic Exhortation VERBUM DOMINI, in which the Pope wrote: 
Wtodzimierz Lapis: The concept of 'logic' and 'logical' in the official documents of the Pope Benedict XVI in comparison with the approach present in John Paul II encyclicals

13. Saint Paul in the First Letter to the Corinthians, states that Jesus Christ died for our sins "in accordance with the Scriptures" (15:3) and that he rose on the third day "in accordance with the Scriptures" (15:4). The Apostle thus relates the event of the Lord's death and resurrection to the history of the Old Covenant of God with his people. Indeed, he shows us that from that event history receives its inner logic and its true meaning. In the paschal mystery "the words of Scripture" are fulfilled; in other words, this death which took place "in accordance with the Scriptures" is an event containing a logos, an inner logic: the death of Christ testifies that the word of God became thoroughly human "flesh", human "history". [sense; game of words and meanings]

The word 'logic' means here 'sense' which is realized in a historical context in accordance with the previous announcement. Therefore, it is worth paying attention to the following two facts:

1) in the herein text logic is expressed by means of a word (The New Testament in reference to The Old Testament)

2) as in the previous quotation from the encyclical Spe Salvi, here we are also dealing with the logic in time sequence.

\section{Different categories of logic}

The distinction between different categories of logic, as it was the case above, is also present in two documents.

In the encyclical CARITAS IN VERITATE, we have 13 instances of words referring to logic (in eight excerpts listed below):

5. Without truth, without trust and love for what is true, there is no social conscience and responsibility, and social action ends up serving private interests and the logic of power, resulting in social fragmentation, especially in a globalized society at difficult times like the present.

6. charity transcends justice and completes it in the logic of giving and forgiving.

34. the logic of gift does not exclude justice, nor does it merely sit alongside it as a second element added from without

36. [Ist part] Economic activity cannot solve all social problems through the simple application of commercial logic. This needs to be directed towards the pursuit of the common good, for which the political community in particular must also take responsibility.

36. [IInd part] The great challenge before us, accentuated by the problems of development in this global era and made even more urgent by the economic and financial crisis, is to demonstrate, in thinking and behaviour, not only that (...) in commercial relationships the principle of gratuitousness and the logic of gift as an expression of fraternity can and must find their place within normal 
economic activity. This is a human demand at the present time, but it is also demanded by economic logic. It is a demand both of charity and of truth.

38. Charity in truth, in this case, requires that shape and structure be given to those types of economic initiative which, without rejecting profit, aim at a higher goal than the mere logic of the exchange of equivalents, of profit as an end in itself.

39. When both the logic of the market and the logic of the State come to an agreement that each will continue to exercise a monopoly over its respective area of influence, in the long term much is lost: solidarity in relations between citizens, participation and adherence, actions of gratuitousness, all of which stand in contrast with giving in order to acquire (the logic of exchange) and giving through duty (the logic of public obligation, imposed by State law).

37. Economic life undoubtedly requires contracts, in order to regulate relations of exchange between goods of equivalent value. But it also needs just laws and forms of redistribution governed by politics, and what is more, it needs works redolent of the spirit of gift. The economy in the global era seems to privilege the former logic, that of contractual exchange, but directly or indirectly it also demonstrates its need for the other two: political logic, and the logic of the unconditional gift.

In the above quoted passages, the author firstly juxtaposes some logic (the logic of power and the logic of the gift of forgiveness), and then states that in appropriate perspective it does not have to be like that. Thus, in the case of those and other related logics (market logic, the logic of equal par exchange and gain market logic, the logic of the state, the logic of exchange, the logic of public behavior, political logic), the word 'logic' means 'sense', 'importance' or 'rules'. Expressing their meaning through the use of the words 'logic' and 'logical', the Pope was thus probably trying to attach greater importance to the described issues. Consider again that in most cases the word 'logic' in these quotations occurs with a noun. Only two times (in the fourth and final quotation), it occurs with an adjective (forming the expression 'market logic' and 'political logic'), which gives it a more dynamic form than in other cases as well as has a more practical dimension. On the other hand, this is a more superficial approach.

Finally, in the last document, the Apostolic Exhortation AFRICAE MUNUS, we considered two citations:

28. The social horizon opened up by Christ's work, based on love, surpasses the minimum demands of human justice, that is to say, giving the other his due. The inner logic of love goes beyond this justice, even to the point of giving away one's possessions: "Let us not love in word or speech but in deed and in truth" (1 Jn 3:18). 
Wtodzimierz Lapis: The concept of 'logic' and 'logical' in the official documents of the Pope Benedict XVI in comparison with the approach present in John Paul II encyclicals

86. The Church is eager to see the globalization of solidarity progress to the point where it inscribes "in commercial relationships the principle of gratuitousness and the logic of gift as an expression of fraternity", while avoiding the temptation to regard globalization as the only lens through which to view life, culture, politics and the economy, and fostering an ongoing ethical respect for the variety of human situations in the interests of effective solidarity.

In the two quotations, the Pope addresses the issues of the logic of love and the logic of gift, and refers to the issue that has been previously described in the encyclical Caritas In Veritate. He wrote there that "love is more perfect than justice and completes it in accordance with the logic of gift and forgiveness,' so similarly here the Pope states that the logic of justice exceeds justice and goes beyond words. Analogous to this, as earlier in the encyclical Caritas in veritate, the Pope opted for the logic of gift, here he is in favour of its introduction.

\section{Summary of Benedict XVI approach}

Benedict XVI in the documents discussed above distinguishes two types of logic: Divine and Human. Even though the Pope differentiates them explicitly yet he states also that placing the human logic in the light of the divine perspective, causes that the distinction mentioned above disappears. The logic included in the Beatitudes constitutes an apogee of such an approach. Given the fact that it was introduced by Christ - in the Christian belief God-Man, in whom the Scripture (Old Testament) was fulfilled, we can talk about a certain logic of history (although in the quoted passage from the Apostolic Exhortation Verbum domini the logic of the history of salvation was discussed and here we would rather discuss the logic of the history of revelation), and (according to the Christian faith) it is a logical consequence of all of God's projects (such type of operation was discussed while describing the passage of the Encyclical Spe Salvi).

\section{The concepts of 'logic' and 'logical' in John Paul II encyclicals ${ }^{1}$}

The Pope by perceiving logic as a science claims that it was founded on the basis of philosophical 'complex systems of thoughts.' Logic is portrayed as a domain in which 'resources of knowledge and wisdom have been substantially enriched,' therefore it enables supporting the development of mankind (literally: is conducive to the development of culture and history') and consequently - is a highly important and significant branch of science.

\footnotetext{
${ }^{11}$ It is a reprint of a paragraph 10. 'Summary' from an article: Lapis W., Analiza pojęć „logika” i „logiczny” w encyklikach Jana Pawła II (Analysis of the concepts of 'logic' and 'logical' in the encyclicals of Pope John Paul II), Investigationes Linguasticae vol. XXIII, Poznań 2011.
} 
While applying the notion 'logical', the Pope states that all people notice the necessity of logical thinking and establishing individual image of the world based on logically consistent systems (which is possible due to the capability for abstract thinking). Logical thinking enables 'drawing correct conclusions', and therefore is an adequate tool even in the hands of a scientist seeking truth. The Pope in his encyclicals uses the notion of a 'logical conclusion' three times. It 'is taken out' (Polish: 'wysuwa się') or 'flows' (Polish: 'płynie'), (thus has a dynamic character and moreover - as in the case of the second notion - it is almost apparent). Even though investigating whether something is logical or not, often requires an indepth analysis', especially related to the reference to the goods and values of higher order.

The Pope always defines logic, understood as a human-made system, as bad or not fully good (describes it then as 'correct yet insufficient' or 'not fully satisfying human needs,' while the logic is intended to serve a man). John Paul II, understanding that logic in its pure form means internal consistency, cannot considered stricte 'human logic', as not meeting that requirement. According to the Pope limiting reasoning to this type of logic ('purely human logic' or 'market logic') is therefore a misguided behavior. In order for a man to thrive, he is obliged to go beyond the limitations of such type of logic (which additionally are for instance 'technocratic logic' or 'logic of pure utilitarianism'). The world should not be described or perceived from the perspective of narrow areas of human activity, yet seen and evaluated in a broader perspective. The logic of this type, being limited as such, put restrictions on human and according to the Pope a man is able to properly understand the world (including himself!) only within the perspective of the logic of the Incarnation.

Finally, the Pope perceives logic as an activity (human or divine) which is thoughtful, rational and oriented towards a specific purpose. Such a perception of logic is dynamic in its nature (in a potential sense - as an idea or factual). The logic for John Paul II is therefore a way to assert the truth. He denotes that such type of human activity, if truthful, should additionally be consistent with the logic of convictions. On the other hand, in accordance with St. Augustine, the Pope recognizes the gradation logicality (actually - illogic) and concludes that logic of 'the evil one' (Satan) is primarily illogical.

All above considerations might be summarized even more briefly by a conclusion that according to the Pope we should not be limited to the narrow logic of men, yet, be guided by activity based on coherent, adequately broad logical systems (although such action can refer both to the constantly widening resources of logic as well as our own 'logical intuition'). 
Wtodzimierz Lapis: The concept of 'logic' and 'logical' in the official documents of the Pope Benedict XVI in comparison with the approach present in John Paul II encyclicals

\section{Comparison of the approaches of John Paul II and Benedict XVI to the understanding of the concepts of 'logic' and 'logical' in papal documents}

In the case of John Paul II the research material is substantially broader (owing to his longer pontificate) than for Benedict XVI, therefore (given that they referred to 'logic' and 'logicality' with more or less the same intensity) reference to the discussed issues is also broader.

As it might be noticed, John Paul II perceives logic both as a science and a domain of human activity. At the same time he states that in everyday life it usually has only partial character/is a partial response and therefore describes the world in a distorted way. A man is able to understand the world properly only within the perspective of logic in a relationship which takes place in the person of the God-Man (i.e. Christ) from the perspective of God.

Benedict XVI approaches the subject from a different viewpoint as he presupposes the existence of divine and human logic (and in the case of the latter, makes no subdivision). What also varies is the way he solves the issue of human vs. divine logic. The 'technocratic rationalism' of logic , shown as its improper aspect,. is opposed to the irrational (from the human viewpoint) aspect of the eight Beatitudes. However, when a man against his judgement undertakes to accept such logic (logic of eight Beatitudes), then the division into the divine and human logics disappears, which overall proves out to be beneficial (both from the divine perspective and - then as well - human).

Both Popes perceive the dynamic aspect of logic, yet John Paul II sees the pursuit of truth as its objective, while Benedict XVI - points that the aim is the salvation of mankind within the historical aspect. In this case, Benedict XVI approaches the issue from a distance while John Paul II is standing almost at the side of a man. 


\section{Bibliography}

Polish dictionary, volume 2: L-P, PWN, Warszawa 1988, p. 49-50 - definitions of notions referred herein.

www.nauczaniejp2.pl/dokumenty (access: 12 III 2012).

Lapis W.: Analiza pojęć „logika” $i$,logiczny” w encyklikach Jana Pawła II (Analysis of the concepts of 'logic' and 'logical' in the encyclicals of Pope John Paul II) in: Investigationes Linguisticae, Volume XXIII, Poznań 2011, p. 61-81.

http://w2.vatican.va/content/benedict-xvi/pl/encyclicals.index.html\#encyclicals (access: 6 VIII 2016).

http://w2.vatican.va/content/benedict-xvi/pl/apost_exhortations.index.html (access: 6 VIII 2016). 